\title{
O SENTIDO DA VACINA OU QUANDO O PREVER É UM DEVER*
}

\author{
THE MEANING OF VACCINE OR \\ WHEN PREDICTING IS A DUTY
}

Myriam Bahia Lopes**

LOPES, M. B. 'The meaning of the vaccine or when the predicting is a duty'. Historia, Ciências, Salide - Manguinhos, III (1): 65-79, Mar.-Jun. 1996.

From the perspective of bistoriography, the article analyzes the construction of scientific medicine's major landmark: the small-pox vaccine. When this vaccine was created and widely distributed, the medical field demonstrated bow technology controls life on a planetary scale. The great victory of scientific medicine rests on the fact that today the life of the small-pox virus depends upon laboratory conditions. Born in England during the 1870's, the anti-vaccine movement questioned universal, mandatory small-pox vaccination. The article examines some metaphors and analogies used by physicians and historians, revealing the process by which the vaccine, as a phenomenon, was constructed.

KEYWORDS: bistoriography, vaccine, small-pox, anti-vaccine movement.

\footnotetext{
* As reflexões contidas neste artigo integram a tese Corpos inscritos: vacina e biopoder. Londres e Rio de Janeiro: $1840-1904$. O trabalho contou com financiamento do CNPq e vem sendo orientado por Michelle Perrot.

** Historiadora.

Rua do Campo, 74

Vila Velha - ES

29100-970

1 Ana Maria Faria mostra
como, pela veiculação
da metăfora da defesa,
usada para descrever os
mecanismos do sistema
imunológico, identifica-
mos uma forma de pen-
sar da medicina reco-
nhecida pela corpora-
ção até os nossos dias
(Vaz e Faria, 1994, pp.
$28-142$ ).
}

\section{O evento vacina}

O desaparecimento da variola no planeta é um fato incontestável. A cura do último caso de varíola foi registrada em outubro de 1977, em Merka, na Somália. Face a este quadro, surge logo a pergunta: por que estudar os movimentos contra a vacina antivariólica? Como estabelecer a história de uma luta contra uma prática vencedora?

Em primeiro lugar, gostaríamos de destacar um ponto na nossa leitura da historiografia da vacinação: a vitória desta prática preventiva é o pilar da credibilidade do modelo imunológico em vigor. ${ }^{1}$ Este modelo, no entanto, desperta críticas. Um imunologista que deseja ampliar o campo de pesquisa desta ciência assinala as suas deficiências. Fundada sobre crenças, a imunologia não responde a uma questão fundamental: como cada organismo reage ao contato com o agente da doença em estudo? ${ }^{2}$

Vaz (1981) estuda as origens da imunologia no século XIX e denuncia o caráter dogmático do modelo desta ciência. Aproximase em vários pontos de sua análise do discurso dos antivacinistas. Para estes últimos, as medidas de higiene pública e privada incluindo-se aí a adoção da tecnologia da engenharia sanitária e uma boa nutrição — tornam a vacinação uma prática desnecessária. ${ }^{3}$ 
2 Segundo Vaz, diversos fatores fizeram o sucesso do combate à variola. Entre eles temos: a inexistência de casos crônicos, o que facilitou a notificação; a inexistência de um reservatório do vírus em outros animais; e a duração da imunidade adquirida com a vacinaçõo (Vaz e Faria, 1994).

3 Contemporâneo ao nascimento da bacteriologia, o movimento antivacinista inglês publica o seu primeiro periódico, The Antivaccinator, em 1869 , enquanto o movimento universal antivacinista é criado em 1880. Paralelamente, Pasteur é premiado pela Assembléia Nacional pelo resultado da vacina contra o carbúnculo em 1874. As últimas décadas do século XIX são marcaclas pelas descobertas dos agentes do tifo, lepra, malária, tuberculose, tétano, botulismo, peste, dentre outros.

4 "A idéia das vacinas está baseada em uma concepção equivocada sobre à organização dos sistemas biológicos. Não se trata de argumentar contra as vacinas que funcionam e estão incorporadas às práticas sanitárias, mas sim de compreender que elas não resultaram do que supunhamos. Resultaram de outros processos que também não entendemos ainda" (Vaz e Faria, 1994).

5 De um lado, o pus vaccinico era transportado em lâminas e em tubos capilares. Numerosas são as reclamações sobre a ausência de resultados na vacinação devido ao emprego de material alterado no acondicionamento e no transporte da vacina. (Ver Ministério dos Negócios Interiores do Império, 1854, pp. 1889 e 282.) Agradecemos a Jaime L. Benchimol pela indicação destes documentos. De outro, acontecia com freqüên-
A despeito da distância temporal que separa os dois discursos, ambos convergem para um objetivo comum. Eles questionam a forma de pensar da medicina solidária à construção do evento científico da vacina. Ambos enfocam o olhar perscrutador do agente específico da doença (idem, 1981, pp. 1.444-7). Mas, ao contrário do que poderíamos supor, Vaz não cita o movimento antivacinista, mesmo quando denuncia os efeitos nefastos da concentração de renda e associa a doença à pobreza e ao processo de urbanização. E, apesar de tudo, a varíola foi erradicada e a vacina antivariólica foi eleita o protótipo da imunologia. ${ }^{4}$

$\mathrm{Na}$ atualidade científica, a vacina antivariólica não é questionada. Uma vez que a varíola foi extinta do planeta, o tema perdeu valor no mercado de citações das revistas científicas. A vacinação antivariólica não é mais objeto de debate na seção métodos e técnicas dos artigos. Ao mesmo tempo, ela se transforma numa peça de museu. A prática da vacinação antivariólica é representada como o ato inaugural da medicina científica.

Sendo registrada como o grau zero da imunologia, a vacina é o ponto de apoio a partir do qual a evolução das ciências biomédicas toma sentido. Nós, historiadores, diríamos que a vacinação antivariólica é o 'monumento' da imunologia.

Com os instrumentos do método arqueológico elaborado por Foucault, assinalamos "a tirania da verdade demonstrativa que esconde a sua base, que é a verdade-evento que se perpetua nos procedimentos" (Kremer-Marietti, 1985, p. 204).

\section{Quando comunicar é prevenir?}

Pasteur elabora a teoria dos germes - as doenças são causadas por microrganismos e podem ser prevenidas pela aplicação de vacinas e soros - e assinala a inovação de seus resultados comparando-os aos de Jenner (1749-1823). Por ocasião da invenção da vacina contra o carbúnculo, Pasteur ressalta que ele foi o primeiro cientista a descobrir um método generalizável para atenuar os agentes infecciosos no laboratório.

Identificar e isolar o agente infeccioso, controlar a sua virulência para melhor comunicá-lo são as fases do método pastoriano de produção de vacinas. Ao acenar com a possibilidade de se fixar ${ }^{5}$ um estado do agente infeccioso, este método ataca a questão da "degenerescência da linfa". Acompanhando as discussões sobre este tema, vislumbramos as dificuldades enfrentadas no transporte e na universalização da vacina antivarióica.

Já no início do século XIX, o desenvolvimento da vacina animal - embora de aplicação restrita a algumas cidades italianas - visa coibir a transmissão da sífilis pela "vacina humanizada". Sendo a vaca refratária ao vírus sifilítico e extraindo-se a 'linfa' diretamente do 
cia que, na vacinação sucessiva de braço a braço, a virulência do vírus se alterasse, ou outros agentes patogênicos fossem transmitidos de indivíduo a indivíduo.

6 A traducão deste e demais trechos é de responsabilidade da autora. animal, não há transmissão da sífilis. Somente em 1864, a partir do pronunciamento do dr. Palasciano, diretor do Hospital de Nápoles e um dos mentores da Cruz Vermelha, no Congresso de Lyon, a técnica de produção da vacina animal ganha ampla divulgação. Desenvolvida pelos drs. Troja e Galbiati, a vacina animal vinha sendo empregada desde 1802 na cidade de Nápoles.

Em 1886, na Alemanha, introduz-se a glicerina para purificar e conservar a vacina. Mas somente no século $\mathrm{XX}$, com o isolamento por filtragem do vírus da varíola e do cow-pox, é que se efetiva a técnica de controle da qualidade da vacina. Afastase assim o risco de transmissão, pela vacina, de outros agentes patogênicos já observados nas pústulas vacínicas. Além da produção da vacina no vitelo, desenvolve-se, por volta de 1930, a cultura do vírus vacínico em ovo embrionado.

Mas voltemos a Jenner (1801, p. 14) e à exemplar imagem que cria do destino do lobo na civilização:

"The deviation of man from the state in which he was originally placed by nature, seems to have proved to him a prolific source of diseases. From the love of splendor, from the indulgences of luxury, and from his fondness for amusement, he has familiarized himself with a great number of animals which may not originally have been intended for his associates.

The wolf, disarmed of ferocity, is now pillowed in the lady's lap." ("O desvio do homem do estado que ele originalmente ocupava na natureza parece ter-lhe demonstrado ser uma fértil fonte de doenças. Do amor à pompa, do vício ao luxo e do seu gosto pela diversão, ele se familiarizou com um grande número de animais aos quais não se tencionava originalmente que ele se associasse.

O lobo, desarmado da sua ferocidade, usa o colo da mulher como travesseiro.") ${ }^{6}$

Jenner cita John Hunter (1728-93) - cirurgião que se tornou célebre pela técnica que desenvolveu para eliminar aneurismas e por seus trabalhos em anatomia comparada - para quem o cachorro é o lobo num estado degenerado. O tema da domesticação dos animais, ou seja, do deslocamento do seu habitat natural, precede a apresentação da vacina e da técnica preventiva.

Observamos o emprego desta imagem nos cadernos de laboratório de Pasteur. Por ocasião das experiências com a raiva, Pasteur (1995, f. 75) ressalta a importância da "aclimatação" do vírus, ou seja, dele ir se 'acostumando' ao novo meio após sua passagem do cão ao coelho e vice-versa: "Comment peut s'expliquer la virulence plus grande de tel ou tel virus? ... . Je crois que c'est affaire d'accoutumance dans un milieu." ("Como explicar uma virulência maior neste ou naquele vírus? ... Eu acredito que seja o acostumar-se ao meio" (idem, f. 10]). 
7 Podemos isolar um agente em cada doença infecciosa? Para cada agente pode ser obtido um soro ou uma vacina? Após realizado o seminário que deu origem a esta publicação, tivemos acesso ao artigo de Vaz e Faria (1995).
8 Sydenham $(10.9 .1624$ - 29.12.1689) foi amigo e correspondente de Locke. Eles elaboraram juntos um estudo sobre a variola.
A idéia de isolar o agente infeccioso no laboratório e domar a sua virulência enforma o método de Pasteur.

A demonstração da eficácia profilática da vacina é reproduzida pelos médicos em detrimento do reconhecimento dos limites da teoria dos germes (Caddedu, 1987, pp. 262-3). Os cientistas alheios às limitações dos procedimentos buscam criar novas vacinas e revalidar a teoria.

Com o surgimento da Aids, questões-desafios à imunobiologia ${ }^{7}$ são veiculadas nos meios de comunicação de massa.

\section{A história e o sentido da vacina}

Em nosso trabalho, partimos da polarização entre dois grupos face às estratégias de prevenção da varíola. Mas, no decorrer de nossa análise, não visamos cristalizar estas oposições. Através da leitura do embate entre os vacinistas e seus adversários, buscamos acompanhar o processo de consolidação da prática da vacina. $\mathrm{E}$, pela análise dos textos que versam sobre o triunfo da vacina, captamos um estilo de registro da história.

Se prever designa a capacidade de ver hoje o quadro futuro, mostramos como a arte de governar a população se encontra com o estilo da história das epidemias.

O conceito de epidemia designa uma doença que atinge um grande número numa dada população. Como veremos, o espaço e o tempo se entrecruzam na definição da epidemia. Assim temos um momento e um lugar: Rio de Janeiro, varíola, 1797. O médico das epidemias demonstra a distribuição de doenças infecciosas num percurso narrativo. No seu texto, paisagens e épocas se conjugam na descrição da incidência da varíola no planeta.

Este estilo narrativoé formulado a partir do que Foucault denomina medicina das espécies. Mas, diferentemente desta última, o conceito de epidemia pressupõe uma percepção quantitativa e cardinal da doença. Sydenham (1844, pp. 10-1) declara: "Na minha opinião o progresso da nossa arte exige ... em primeiro lugar uma história de todas as doenças, quer dizer, uma descrição elaborada da natureza."

Sydenham compara o trabalho do médico ao do pintor hábil. Pela descrição, ele separa os fenômenos próprios à doença daqueles que lhe são acidentais. O método de Sydenham visa classificar as doenças em espécies em função de sua história; isto é, pesquisar a "maneira como a natureza produz e mantém as diferentes formas de doença" (idem, p. 390). A elaboração de um catálogo dos fenômenos naturais é o ponto de partida da ciência operativa.

\section{Vacina: forma e tempo}

Nunca é demais mencionar o resultado obtido por Jenner. Este médico observador reproduz um fenômeno conhecido entre os 
9 Em 1801, o médico suíço dr. Odier (17481817 ) propõe o termo vacina em substituição a cow-pox (Canguilhem, 1988 , p. 55).

10 Para Silverstein, estas informações ilustram que, na época de Jenner, a climensão numérica da amostra não é um elemento relevante (Silverstein et al, 1981, p. 445). Se aceitamos esta premissa, como explicamos o quadro de 504 casos elaborado pelo dr. Moseley, crítico contemporâneo de Jenner?

11 o reconhecimento social da habilidade do vacinador é fruto do debate sobre a técnica da vacinação antivariólica. Assim sendo, veta-se às mães o direito de vacinar os filhos clurante o sono, em nome cla garantia da verdadeira vacina. A prática da vacina é restringicla ao saber-poder dos profissionais da saúde (Darmon, 1986).

12 Denarp (1851). Os desenhos publicados neste trabalho foram feitos a partir de uma coleção de peças.

Anne Marie Moulin (1991, p. 37) cita o empenho de André Fasquelle em fazer uma semiologia das pústulas. camponeses. A doença dos cascos dos cavalos, conhecida como the grease, é transmitida às vacas pelas mãos humanas. Em volta das tetas das vacas aparecem pústulas que testemunham a infeçcão do animal. Em seguida, o contato do homem com as pústulas durante a ordenha permite a transmissão da doença ao homem. Aquele que contraiu o cow-pox se torna imune à varíola.

Jenner escolhe uma criança e a inocula de cow-pox. ${ }^{9}$ Depois, a 'linfa' de um doente com um caso grave de varíola é inoculada na criança. Por meio desta operação, Jenner produz a prova da eficácia da imunização. Ele recompensa a família da criança com a doação de uma casa. Nos 23 casos relatados por Jenner, sete se referem à inoculação do vírus do cow-pox, tendo sido testada a imunidade em apenas dois casos. ${ }^{10} \mathrm{~A}$ astúcia de Jenner é substituir o vírus da varíola pelo do cow-pox: aquele que foi inoculado pelo vírus do cow-pox conseguirá se resguardar da varíola.

Com o gesto vacinal o médico introduz a 'linfa'. A erupção na pele testemunha a infecção. As transformações da pústula são o índice do sucesso ou fracasso da operação. Surge toda uma discussão sobre a falsa e a verdadeira vacina. ${ }^{11}$ A maturação da pústula dos vaciníferos marca o tempo de atuação dos vacinadores. A 'linfa' deve ser colhida em dias específicos, quando a pústula apresenta características bem determinadas. Com uma lanceta e de braço a braço, o transporte da vacina se realiza até continentes distantes. A vacina chega ao Brasil em 1804.

A cicatriz torna-se a prova da imunidade adquirida pela vacinação. ${ }^{12}$ Visível na pele e legível nos números das estatísticas, o sucesso desta prática médica é demonstrado.

Apesar de algumas divergências, a transferência de Jenner ganha o selo de fato científico. Em 1802, ele envia uma petição à Câmara dos Comuns solicitando emolumentos pela originalidade da sua descoberta.

Nas duas últimas décadas do século XIX, Koch e Pasteur generalizam e transformam o princípio de imunidade da vacina. Os cientistas buscam identificar o agente de cada doença transmissível e controlar a sua virulência no laboratório para fabricar uma vacina.

\section{Heteroprofilaxia}

Pasteur apóia-se no princípio da imunidade adquirida, mas não indaga nos seus escritos como uma doença, o cow-pox, pode resguardar o corpo de outra, a varíola. Entre os antivacinistas esta questão é recorrente e a ausência de resposta por parte dos defensores da vacina se transforma em denoncia: "What they are doing they really do not know ..." ("O que eles estão fazendo na verdade eles não sabem ..." [Tebb, 1899, p. 3].) 
13 Os antivacinistas ingleses da clécada de 1880 se apóiam nos estudos do dr. Creighton e do prof. Crookshank, onde são enunciadas as diferenças entre o cowpox e a varíola.
Para os antivacinistas a vacina jeneriana e o princípio de heteroprofilaxia não têm base científica. ${ }^{13}$

A vacina é concebida por Jenner a partir do olhar da história natural. No tratado An inquiry into the causes and effects of the variolae vaccinae que Jenner faz publicar em 1798, ele inclui quatro ilustrações a cores das mãos e dos braços da ordenhadeira Sarah Nelme, desenhadas por Edward Pearce e gravadas em cobre por William Skelton.

Nós nos perguntamos: até que ponto a configuração das pústulas do cow-pox e da varíola se alinham na descoberta? No olhar de Jenner (1857, p. 2), médico e naturalista, se figura o analogismo entre a pústula da varíola e a pústula do cow-pox:

"Here the close analogy between the virus of small-pox and of cow-pox becomes remarkably conspicuous ... but when taken in a far advance stage of the disease (although taken early) previously to its insertion, it may be exposed to such agent according the established laws of nature, cause its decomposition, it can no longer be relied on as effectiveness. This observation will fully explain the source of those errors which have been committed by many inoculators of the cow-pox." "Aqui a analogia entre o vírus da varíola e o do cow-pox se torna extraordinariamente manifesta ... mas quando extraída num estágio avançado da doença, antes da sua inserção, ela pode ser exposta aos agentes que, segundo as leis estabelecidas pela natureza, causam sua decomposição, ela não pode ser creditada como eficaz. Esta observação explica inteiramente a fonte de erros cometidos por muitos inoculadores do cow-pox.")

Em que sentido a evidência na pele orienta o saber operativo da medicina? "A pústula vacínica jamais se confunde com qualquer outra, seu caráter, sua marcha lhe é particular” (Muzi, 1834, p. 16). Se, para Jenner, ela induz a aposta na heteroprofilaxia, para os antivacinadores estabelece um parentesco essencial entre a lepra, a sífilis e a varíola com a possibilidade da transmissão destas doenças pela vacina.

Para os antivacinistas, ao invés da erupção da pústula da vacina e a confirmação da técnica profilática, temos o desenvolvimento de "acidentes secundários da sífilis".

O reconhecimento deste espaço de vizinhança das doenças não é estranho a Jenner. Entre os cuidados preconizados com a vacina, Jenner (1804) desaconselha a vacinação antivariólica em corpos com antecedentes de eczema.

O dr. Jean de Carro (1750-1857), médico suíço instalado na Áustria e diplomado pela Universidade de Edimburgo, é adepto do termalismo e divulgador da prática da vacina. Introdutor da vacina em Viena, assinala (1854): "la parenté, depuis si long- 
14 O trabalho de Moseley é comentado na tese defendida na Faculdade de Medicina clo Rio de Janeiro (FMRJ) em 1873 (ANM $1873 \wedge \mathrm{C} 1$, p. 4).
15 Sobre as práticas de dissecção anatômica, vale a pena citar os estudos de Richardson (1987) e Linebaugh (1977) e o artigo de Rupp (1993). temps prouvée, qui existe entre l'éruption du pis des vaches ...et l'éruption de la variole ..." ("há tempo foi provado o parentesco entre a erupção das tetas das vacas ... e a erupção variólica").

No início do século XIX, o dr. Moseley, médico do hospital militar de Chelsea e membro do Colégio de Medicina de Londres, é o primeiro inglês a advertir sobre a possibilidade de transmissão da sífilis pela vacina. Ele relata ter sido testemunha de 504 casos de erupção de pústulas generalizadas e persistentes após a vacinação do que ele denominou de sarna vacinal (cow-poxitch), incluindo-a no quadro nosológico da sífilis. ${ }^{14}$

Fleck, ao tratar da origem do conceito de sífilis, mostra como ele incluía, além do que chamamos hoje de sífilis, a lepra, a sarna, a tuberculose da pele, a micose, a varíola, nas regiões tropicais, a elefantíase e várias outras doenças não específicas (Carrara, 1995, p. 6).

$\mathrm{Na}$ medicina das espécies, "em um mundo plano, homogêneo, não métrico, existe doença essencial onde há pletora de analogias" (Foucault, 1980, p. 5).

Segundo alguns biógrafos, Jenner desperta a atenção para o cow-pox no período de sua formação em medicina. Nessa época, Jenner é aluno do cirurgião e professor de anatomia comparada, dr. John Hunter, tendo se tornado seu correspondente. O dr. Hunter é um ousado adepto da técnica da inoculação. Durante o século XVIII, a técnica de inoculação do vírus da varíola de uma epidemia branda para se prevenir do ataque da varíola confluente era largamente utilizada na Europa.

O dr. Hunter, que defende a unicidade entre a blenorragia, a sífilis e o cancro, se inocula o vírus da sífilis (Hunter, 1786). Ele mobiliza os seus sentidos para estudar experimentalmente a sífilis. Seu corpo se transforma em um quadro vivo da doença que se apaga por ocasião da sua morte, anos após a inoculação experimental (Proust, 1985).

O dr. William Hunter (1718-93), irmão mais velho do dr. John, é professor de anatomia na Royal Academy of Arts de Londres (Debord, 1985). Ele desenvolve um método de produção de modelos anatômicos. O dr. Hunter pega o corpo do criminoso enforcado ainda quente, disseca e modela o corpo até obter dele uma atitude. A técnica antecipa a rigidez da morte. O cirurgião é temporariamente seu aliado para vencê-la em seguida. No dia seguinte, quando a morte fixa uma posição e os músculos perdem a sua plasticidade, Hunter enforma o cadáver. Ele prossegue o trabalho no corpo registrando sua marca no suporte imortal do modelo artístico. $O$ 'contrabandista' criado por Hunter entra na galeria dos cânones artísticos. O transporte do corpo liga a prisão, a forca, a mesa de dissecção, o anfiteatro e o museu. ${ }^{15}$ 
16 A. Russel Wallace faz uma demonstração contra a vacinação usando os dados da marinha inglesa. Este estudo é citado no Congresso da Liga Universal contra a Vacina Antivariólica de 1885, realizado em Charleroi, Bélgica. A liga é fundada pelo médico belga dr. Hubert Boëns (Congrès Charleroi UM 130136, 1885 , p. 131).

\section{Margens}

A partir da medicina das espécies, o médico deve se habilitar a transcrever no papel a história da doença. Ele deve saber alinhar os sintomas de maneira a estabelecer margens que, superpostas, facilitem a comparação.

Comparar os vários países, comparar o presente com o futuro como índices da arte de governar. Na história das epidemias, observamos um processo de coleta, unificação e circulação de provas, estejam elas sob a forma de estatísticas, fotos, desenhos ou narrativa histórica.

Em 1802, o ministro conde de Anadia adota a seguinte estratégia de difusão da vacina jeneriana. Ele solicita ao vice-rei e aos capitães-gerais a adoção desta prática enviando-lhes exemplares de uma publicação de médico luso-brasileiro, intitulada: 'Preservativo das bexigas e de seus terríveis estragos, ou história da origem, e descobrimento da vacina, e dos seus efeitos ou sintomas, e do método de fazer a vacinação' (Paiva, 1801).

O aumento da circulação de informações ganha novo ímpeto com o surgimento da imprensa ilustrada e a invenção da fotografia. Tanto os desenhos como as fotografias são provas utilizadas pelos vacinistas e seus adversários. Os dois grupos visam demonstrar que o seu discurso é o único científico.

\section{A precisão dos números}

A estatística é a arte de interpretação dos fenômenos numéricos de grande ordem ou dos fenômenos complexos. Face à diversidade, a estatística tenta fixar regras, e diante do acaso ela estabelece leis. Ela se apresenta como a ciência que responde com certeza às questões colocadas. A estatística traduz em números um fenômeno dado. Ela se mostra como uma ciência precisa, pois calcada nos modelos matemáticos. No entanto, ela não escapa às questões sobre o método de interpretação. $O$ paradoxo deste saber é que a verdade é relativa. Ela varia segundo a forma como o cientista questiona o fenômeno que ele enuncia e analisa. Nesse sentido, olhares distintos do mesmo fenômeno são possíveis. O que, na polarização da luta, nenhum grupo admite.

Em torno do tema da vacinação ocorre uma guerra de estatísticas. O naturalista inglês e co-autor da teoria da evolução das espécies, Alfred Russel Wallace, ${ }^{16}$ participa com estudos estatísticos da defesa da causa antivacinista.

A década de 1840 é um marco dessas transformações e do início das campanhas de vacinação antivariólica. Em 1840, termina a vacinação feita por filantropos na Inglaterra. O parlamento inglês vota o primeiro ato de vacinação proibindo a variolação. 
17 Algumas datas da história institucional da vacina nas primeiras clécadas do século XIX. Fm 1808, é criado o National Vaccine Institute. Três anos clepois é criada a Junta da Instituição Vacínica na cidacle do Rio de Janeiro, e, em 1832, o Código de Posturas estabelece a primeira lei brasileira de obrigatoriedade da vacina.

18 Tendo como tema principal o movimento antivacinista foram publicados apenas os seguintes artigos Beck (1960); Huerkamp (1985); MacLeod (1967); Nelson, e Rogers (1992).

19 Citando apenas dois exemplos: Darmon (1986, p. 169) e Falcao (1972).

20 De circulação restrita à corporação médica citamos ainda uma tradução publicada na Gazela Médica do Rio de Janeiro, de 1868, e três teses médicas defendidas na FMRJ, em 1873.
De uma certa forma, a criação do Registro Geral de Estatística, em 1837, prepara o lançamento da vacina como prática universal gratuita. Se a vacina chega ao Brasil em 1804, em 1832 ela será objeto de regulação do Código de Posturas, que a transforma em medida obrigatória. Já no início da década de 1840, os médicos brasileiros discutem a necessidade de revacinação para se garantir a imunidade à variola. ${ }^{17}$

\section{O debate subtraido}

A historiografia ${ }^{18}$ trata o movimento antivacinista de forma negativa. A existência de críticos à vacina é vista como um obstáculo, uma resistência ao desenvolvimento das ciências da vida. ${ }^{19}$ A historiografia reproduz os recortes temporais criados durante a disputa entre estas duas figuras do saber, ou melhor, entre os vacinistas e seus adversários.

A estratégia usada no combate se transforma em sentido da história. O grupo vencido pertence a um passado que insiste em existir no presente. Do outro lado, os vencedores são homens clarividentes, progressistas e incompreendidos em sua época. Quando a batalha termina, os vencedores são aqueles que liberam os obstáculos que impediam o tempo correr do passado ao futuro. Nesta versão, a palavra resistência pressupõe duas forças que apontam para direções opostas. Entre o passado e o futuro, os combatentes fazem o tempo passar e o vencedor será aquele que conseguir acertar a flecha do tempo.

Nesta construção da história, várias metáforas ligam a razão e o progresso às luzes e à velocidade. Assim, como veremos adiante, para os médicos brasileiros admitir os problemas relativos à vacinação e se deter neles para estudá-los é perder tempo. Se, além das dificuldades operacionais de pesquisa que colocam os profissionais brasileiros em posição de desvantagem com relação aos colegas europeus, os médicos gastarem os seus parcos recursos em expor as dúvidas que surgem, o Brasil nunca fará ciência. Dessa maneira, de uma constatação geral - as verbas de pesquisa são reduzidas - se desdobra um posicionamento da corporação.

A conduta dos médicos brasileiros traz implicações importantes para o nosso trabalho. Enquanto na Inglaterra o debate sobre a transmissão de doenças pela vacina conta com ampla publicidade, ele se mantém restrito no Brasil. Se as fontes dos antivacinistas ingleses são fartas, no Brasil elas se resumem basicamente aos textos da Igreja e Apostolado Positivista do Brasil. ${ }^{20}$

O modelo que associa a razão e o progresso às luzes e à velocidade ganha ainda mais força quando acrescentamos os termos modernização e saúde pública. Estas foram as palavras de ordem da campanha de remodelação, também denominada de 
21 Em outra ocasião analisamos a historiografia relativa a este período (Bahial Lopes, 1988, capítulo I). 'regeneração', da cidade do Rio de Janeiro, ocorrida no início deste século. ${ }^{21}$

Desde que a historiografia não se aventura a criticar a construção do fato científico, os antivacinistas ficam relegados à produção de um discurso falso. As questões levantadas pelos antivacinistas perdem o seu contexto. A introdução da prática da vacinação antivariólica é contada como a implacável vitória da ciência e da verdade. Um importante deslocamento é feito. Empregando-se a analogia com a guerra, o debate sobre a vacina é reduzido a dois grupos em combate, quer dizer: de um lado, os vacinistas e, de outro, os antivacinistas. E a vitória contra a varíola torna-se a vitória contra os antivacinistas.

\section{Recolocando algumas questões}

A Organização Mundial de Saúde reconhece a eficácia de 14 vacinas humanas, apesar de existirem mais de duzentas doenças infecciosas. Se o modelo da imunologia revelou-se um fracasso no que diz respeito às doenças parasitárias, a invenção das vacinas antibacterianas garantiu seu sucesso. Entretanto, como nos revela Nelson Vaz, o funcionamento da maior parte das vacinas sobre o organismo não tem explicação.

O modelo imunológico é fundado no século XIX e os mecanismos que preservam o organismo da doença são apresentados como um sistema de caixa-preta. Quando a teoria dos germes é enunciada, Koch e Peter acusam Pasteur de generalizar os resultados obtidos e de ir rápido demais nas implicações que infere de suas experiências (Latour, 1993, p. 36).

Gostaríamos de mostrar como o sucesso da vacinação, o fato de a varíola ter sido extinta do planeta, impede que avancemos na crítica à historiografia da vacina. Quando o tempo da história é identificado ao ritmo do progresso, o sentido da ação passa a ser um a priori do discurso médico.

Como vimos, a história das epidemias é uma história comparativa do estado da doença em vários países e em várias épocas. Esta configuração norteia a elaboração das campanhas contra a varíola. O pano de fundo do discurso médico é a projeção de um mundo sem varíola. E, visando este objetivo, é escrita a história da ascensão e da queda da varíola onde os médicos aliados ao poder público cumprem o papel de heróis dessa 'odisséia'.

\section{Comparar e projetar}

Gostaríamos de mostrar como, por um recorte espacial que coincide com os limites geopolíticos do país, se constrói uma dinâmica da história. A descrição do que foi feito e do que deve 
22 Com relação à crítica dos antivacinistas a este argumento, ver National Anti-Vaccination League, s. d.
23 o dr Aureliano Portugal é autor, dentre outros, de artigos veiculados na imprensa médica carioca e do Relatório sobre o Estado Sanitário da Cidade do Rio de Janeiro, publicado em 1893. Este médico ocupa o cargo cle diretor da Divisão de Estatística do Arquivo do Distrito Federal de 1907 a 1924. ser se pauta por uma concepção finalista da história, onde a ação vem preencher uma ausência, um vazio, uma falta. Tudo que precisamos está lá fora. E, aos leitores céticos, aconselhamos que olhem para outros países, onde o que queremos construir já existe. Assim, temos a demonstração em grande escala da eficácia da vacinação em 1870, quando da guerra entre a França e a Alemanha. A Inglaterra menciona o sucesso da Alemanha com a introdução da vacina obrigatória. ${ }^{22} \mathrm{O}$ Brasil cita a Europa. A França cita a Inglaterra. Cada país produz um espelho através do qual olha os outros e também o seu futuro.

$\mathrm{Na}$ Inglaterra, a história mundial da vacina antivariólica é contada nos relatórios parlamentares. Durante o século XIX, os ingleses produzem vários relatórios oficiais, onde incluem a consulta a diversos especialistas de outras nações.

Tanto os antivacinistas como seus adversários montam redes de informações e promovem encontros internacionais. Num congresso da Liga Universal dos Antivacinistas, fundada pelo médico belga, dr. Hubert Boëns, Tebb, presidente do comitê executivo da Sociedade Londrina pela Abolição da Vacina Obrigatória e representante da Inglaterra e dos Estados Unidos no evento, assinala:

"l'échange des idées et la comparaison des résultats acquis doivent avoir pour effet de fortifier notre cause et de la remplir d'une nouvelle ardeur... Ce qui est un erreur scientifique dans un pays, ne saurait être une vérité dans un autre. Des pratiques pernicieuses peuvent exister et on existé pendant des générations chez tous les peuples: mais le rejet en sera d'autant plus prompt qu'elles seront attaquées de plusieurs côtés à la fois" (Boëns 1882, p. 50). ("A troca de idéias e a comparação de resultados deve ter por efeito o fortalecimento da nossa causa, deve preenchê-la com um novo ardor... O que é um erro científico num país pode não ser uma verdade noutro país. Práticas perniciosas podem existir e existiram durante gerações em todos os povos, mas a recusa será muito mais forte se atacarmos simultaneamente de vários lados.")

No período de 1889 a 1891, é realizada uma grande enquete na Inglaterra sobre a prática da vacinação antivariólica. Aos médicos, estatísticos e políticos de várias nações é endereçado um questionário solicitando uma avaliação da prática da vacina antivariólica obrigatória.

No Brasil, o inspetor geral de Higiene da Cidade do Rio de Janeiro encarrega o dr. Aureliano Gonçalves de Souza Portugal $(1851-1924)^{23}$ de responder às questões colocadas pela delegação inglesa. O título do relatório, 'Sobre as epidemias no Brasil e os males que dizem ser causados pela vacinação', se apresenta como um índice das preocupações que afligiam os ingleses. No 
seu texto, o médico-demógrafo contorna a questão que the foi feita. $\mathrm{O}$ dr. Portugal evita negar categoricamente a asserção contida na pergunta, quer dizer, ele não quer negar um fato freqüente nos relatórios ingleses, ou seja, a contaminação da 'linfa' e a possibilidade de transmissão da sífilis. Por um lado, este autor lança mão de recursos retóricos para minimizar as críticas endereçadas à vacinação. No lugar de uma conclusão encontramos uma desculpa. O único limite que o relator admite no seu trabalho é a ausência de estatísticas para outras cidades brasileiras. Mas de onde fala o dr. Portugal? Ele se apresenta como a voz imparcial da ciência. De outro lado, ele elabora quadros estatísticos sobre a mortalidade da varíola e sobre a população vacinada.

No discurso científico, a demonstração é feita com provas. Se faltam provas para demonstrar os males causados pela vacinação, não se trata de uma asserção científica. ( $O$ dr. Portugal não menciona o fato de a questão ter sido objeto de estudo de teses de medicina apresentadas no Rio de Janeiro na década de 1870 , onde os autores fazem referência ao debate ocorrido na França sobre a contaminação de sífilis pela vacina). Para este médico, trata-se de um ponto impreciso do domínio da opinião pública, "de males que se diz":

"Quanto aos males alegados entre nós como provenientes da vacina, nada a respeito encontramos nos numerosos documentos que tivemos que consultar e nem mesmo cousa alguma tem-nos constado;

Embora acreditemos que a sífilis e a tuberculose sejam transmissíveis por inoculação e, portanto, pela inoculação da vacina, somos felizes em poder assegurar que entre nós se alguns fatos têm se dado de contágio, por esse meio, eles são tão raros e tão duvidosos que nada tem transpirado.

Se isso se deu até 1889, com a introdução da vacina animal, os perigos da vacina tornam-se nulos, devendo-se considerar como absolutamente isento de inconveniente o grande recurso profilático" (Archivo DF, 1929).

Nosso objetivo aqui é mostrar como é difícil pensarmos a consolidação da prática da vacinação se não analisamos o conceito de história que a enforma. Partimos então de um contexto onde observamos uma situação de polarização: o debate sobre a vacina antivariólica. De um lado, temos os seus adeptos e, de outro, os críticos à vacina. E o que encontramos? Os dois grupos em disputa utilizam os mesmos instrumentos para provarem que o seu discurso é o verdadeiro. $\mathrm{E}$ assim identificamos um estilo comum aos dois grupos. 
LOPES, M. B. 'O sentido da vacina ou quando o prever é um dever'. História, Ciências, SanideManguinhos, III (1): 65-79, mar.-jun. 1996.

Partindo da historiografia, analisamos a construção do monumento da medicina científica: a vacina antivariólica. Ao criar e difundir a vacina, a medicina demonstra como a técnica controla a vida em escala planetária. A grande vitória da medicina científica se funda no seguinte resultado: hoje, a existência do vírus da varíola depende da vida em laboratório. O movimento antivacinista surge na décacla de 1870, na Inglaterra, e questiona a adoção universal e obrigatória da vacina antivariólica. Estudamos algumas metáforas e analogias empregadas por médicos e historiaclores. Elas nos revelam o processo de construção do fato vacina.

PALAVRAS-CHAVE: historiografia, vacina, varíola, movimento antivacinista.

\section{REFERÊNCIAS BIBLIOGRÁFICAS}

\section{Fonte manuscrita}

Ministério dos Negócios Interiores do Império. Correspondência de 1854.

Impressos

Archivo do Districto Federal. Extractos e manuscriptos sobre a vaccina. Rio de Janeiro, ANM, 1929.

Bahia, L. M. 1988

Beck, A. 1960

Boëns, $\mathrm{H}$. 1882

Cacldedu, A. 1987

Canguilhem, G. 1988

Carrara, Sérgio 1995

Carro, J. 1854

Creighton, $\mathrm{C}$. 1887

Darmon, P. 1986

Debord, J.-F. 1993

Denarp Decanteleu, J. E. B.
Práticas médico-sanitárias e remodelação urbana na cidade do Rio de Janeiro: 1890-1920. Tese de mestrado, Campinas, Departamento de História/IFCH/Unicamp.

'Issues in the anti-vaccination movement in England'.

Medical History, IV: 310-21.

La vaccine du point de vue historique et scientifique. Paris, J. Micheld.

'Pasteur et la vaccination contre le charbon: une analyse historique et critique'. History Philosophy of Science, 9: 262-3.

'L'effet de la bacteriologie dans la fin des théories médicales au XIX siècle'. Idéologie et rationalité. Paris, Vrin.

O tributo a Vênus: a luta contra a sifilis no Brasil (de finais do século $X I X$ até os anos 40). Tese de doutoramento, Rio de Janeiro, Museu Nacional.

Appel à Messieurs les médecins vétérinaires, ainsi qu'aux propriétaires de chevaux et de vaches de tous pays. Carlsbad, Fróres Franieck.

The natural history of cow-pox and vaccinal syphilis.

La longue traque de la variole. Paris, Perrin.

'De l'anatomie artistique à la morphologie'. L'âme all corps arts et science 1793-1993. Paris, Gallimard. Exposição realizada no Grand Palais, Paris, 19.10.1993 a 24.1.1994.

Monographie des cicatrices de la vaccine. Paris. 
1985

Falcao

1972

Huerkamp, C. 1985

Hunter, J. 1786

Jenner, E. 1801

Jenner, E. 1857

Jenner, E.

Kremer-Marietti, A. 1985

Lee, $R$.

1868

Linebaugh, $\mathrm{P}$. 1977

MacLeod, R. M. 1967

Moseley 1857

Moulin, A. M. 1991

Muzi, H. O. 1834

National AntiVaccination League

Nelson, M. C. e Rogers, J. dez. 1992

Paiva, M. J. H. de 1977

Pasteur 1995

Richardson, R. 1987

Rupp, Jan C. C. 1993
L'Encyclopédie Diderot et D'Alembert, comentada por Jacques Proust. Paris, Hachette.

Oswaldo Cruz - Monumenta Historica: a incomprenso de uma época. São Paulo, Brasiliense. Col. Monumenta Historica.

'The history of smallpox in Germany: a first step in the medicalization of the General Public'. Journal of Contemporary History, 20: 617-35.

Treatise on venereal disease. Londres, Sold at Castle-Street, Leicester Square.

Inquiry into the causes and effects of the variolae vaccinae. $3^{\text {il }}$ ed., Londres, DN Shury.

'Evidence given before a Committee of the House of Commons, 22.3.1802, em General Board of Health. Papers relating to the History and Practice of Vaccination presented to both Houses of Parliament by Command of her Majesty. Londres, Majesty's Stationnery Office, Appendix.

Medical and Physical Journal, 1804, 12: 97-102. Em A. M. Moulin. op cit, p. 379.

Michel Foucault: archéologie et généalogie. Paris, Librairie Générale, p. 204.

'Liçôes sobre as inoculações sifilíticas e de suas relações com a vacinação'. Gazeta Médica do Rio de Janeiro, 10: 15.5.

'The Tyburn Riot against the Surgeons'. Em D. Hay, Albion's Fatal Tree Crime and Society. Peguin, Londres, p. 73.

'Law, medicine and public opinion: the resistance to compulsory health legislation 1870-1907'. Public Law, pp. 107-28 e 189-211.

'Treatise on lues bovilla, or cow-pox; Commentaries on lues bovilla, or cow-pox e cow-pox epistle to Rowland Hill'. Em General Board of Health, Papers relating to the History and Practice of Vaccination, presented to both Houses of Parliament by Command of her Majesty. Londres, Majesty's Stationnery Office, p. xix.

Le dernier langage de la médecine. Paris, PUF.

Compendio sobre a vaccina. Rio de Janeiro, Typ. Nacional.

Vaccination, the argument from Germany, Londres, A. Bonner.

'The right to die? Anti-vaccination Activity and the 1874 Smallpox Epidemy'. Social History of Medicine, 5, 3: 369-87.

op cit, Lisboa. 1801. Em Lycurgo Santos Filho. História geral da medicina Brasileira. São Paulo. Hucitec/USP, p. 271.

Cahiers d'un savant. Paris, CNRS-ZULMA-BN

Death, dissection and the destitute. Londres.

'Michel Foucault, a política do corpo e a expansão da anatomia moderna'. Physis, 3, 2: 7-42. 
O SENTIDO DA VACINA

Silverstein, A. M. e Miller, $G$. 1981

Sydenham 1844

Sydenham 1980

Tebb, W. S. 1899

Vaz, Nelson M. e Faria, Ana Maria C. 1995

Vaz, N. M. e Faria, A. M. C. 1994

Vaz, N. M. 1988

Vaz, N. M. nov. 1981
'The Royal Experiment on Immunity: 1721-1722'. Cellular Immunology, 61: 437-47.

Opera Omnia. Londres, G. A. Grenhill.

Médecine Pratique. Paris. 1784 , p. 390 . Em M. Foucault, Nascimento da Clínica, Rio de Janeiro, Forense Universitária, p. 4.

A century of vaccination and what it teaches. Londres, Swan Sonnenschein.

'Aids: sintomas de uma crise médica'. Em D. Czeresnia;

E. Moreira dos Santos; R. H. Simões Barbosa e S. Monteiro (orgs.), Aids, ética, medicina e biotecnologia. São Paulo/Rio de Janeiro, Hucitec/Abrasco, pp. 101-35.

Guia incompleto de imunobiologia. Belo Horizonte, Copemed.

Crenças básicas de imuınologia. Belo Horizonte, DBI/ICB/UFMG.

'A face oculta da memória imunológica'.

Ciência e Cultura, 33: 1.444-7.

Recebido para publicação em setembro de 1995. 